\title{
Three Stories About the Exploitation of 'Chocolate' Flint During the Stone Age in Central Poland
}

\section{Dominik Kacper Płaza ${ }^{\mathrm{a}}$ and Piotr Papiernik}

\begin{abstract}
This paper argues that, despite the purely physical nature of the process of the creation of blades that later will be components of multi-material tools, this is also like an artistic act. If this is so, the manner in which we discuss the sequence of blade production can be analysed in much the same way as any other narrative works of art, like Greek literature or Shakespearean drama. The article presents three stories about cores that were used for production of blades for tools during the Stone Age, examining the systematic sequence of actions (like the choice of the raw material, core preparation, blade production, repairs of core and discarding of the exhausted core) in the form of a 5-act dramatic structure. We suggest that these five parts or acts of drama are similar to the manner in which, in Stone Age archaeology, we talk about the knapping sequence and goals of blade production. Observation of three blade cores connected with the late Mesolithic and the Early and Middle Neolithic from the central part of Poland provides an opportunity for discussion about the features of those pieces and searching for similarities and differences in the use of 'chocolate' flint during the latter part of the Stone Age.
\end{abstract}

KEY-WORDS: Late Mesolithic, Linear Band Pottery culture, Funnel Beaker culture, 'chocolate' flint, blade core

\section{INTRODUCTION}

'Chocolate' flint has very good qualities and was very often used for tool production during the Stone Age in Poland. The shape, size and internal features of that raw material caused its popularity in prehistory (Schild et al., 1985; Budziszewski 2008). In our paper, we would like to present three stories about the manner of use of that raw material in the latter part of the Stone Age, analysed in the same manner as a five-act drama or short story according to the well-known methodology adopted by Gustav Freytag (1900). The creation of blades that later would become components of multimaterial tools, despite the purely physical nature of the process, is like an artistic act.

\footnotetext{
a District Museum in Sandomierz; e-mail kacpros@hotmail.com; ORCID: 000o-oooI-6223-2307

b Museum of Archaeology and Ethnography in Lodz; e-mail fba@lodz.home.pl; ORCID: 0000-0002-0970-5627
} 
Just as in the discussion of other works of art, like cave painting or modern music, the story of their production can be analysed as such in the same way as Greek literature (as Aristotle did in his 'Poetics') or Shakespearean drama. We think that the systematic sequence of actions in the knapping process (like the choice of the raw material, core preparation, blade production, repairs of core and discarding of the exhausted core) resembles a 5-act dramatic structure. We argue that these five parts or acts of drama are similar to the manner in which, in Stone Age archaeology, we talk about the knapping sequence and goals of blade production.

We will focus on blade cores, which are an important component of the knapping sequence; the material used as an example in our analysis are three cores of the late

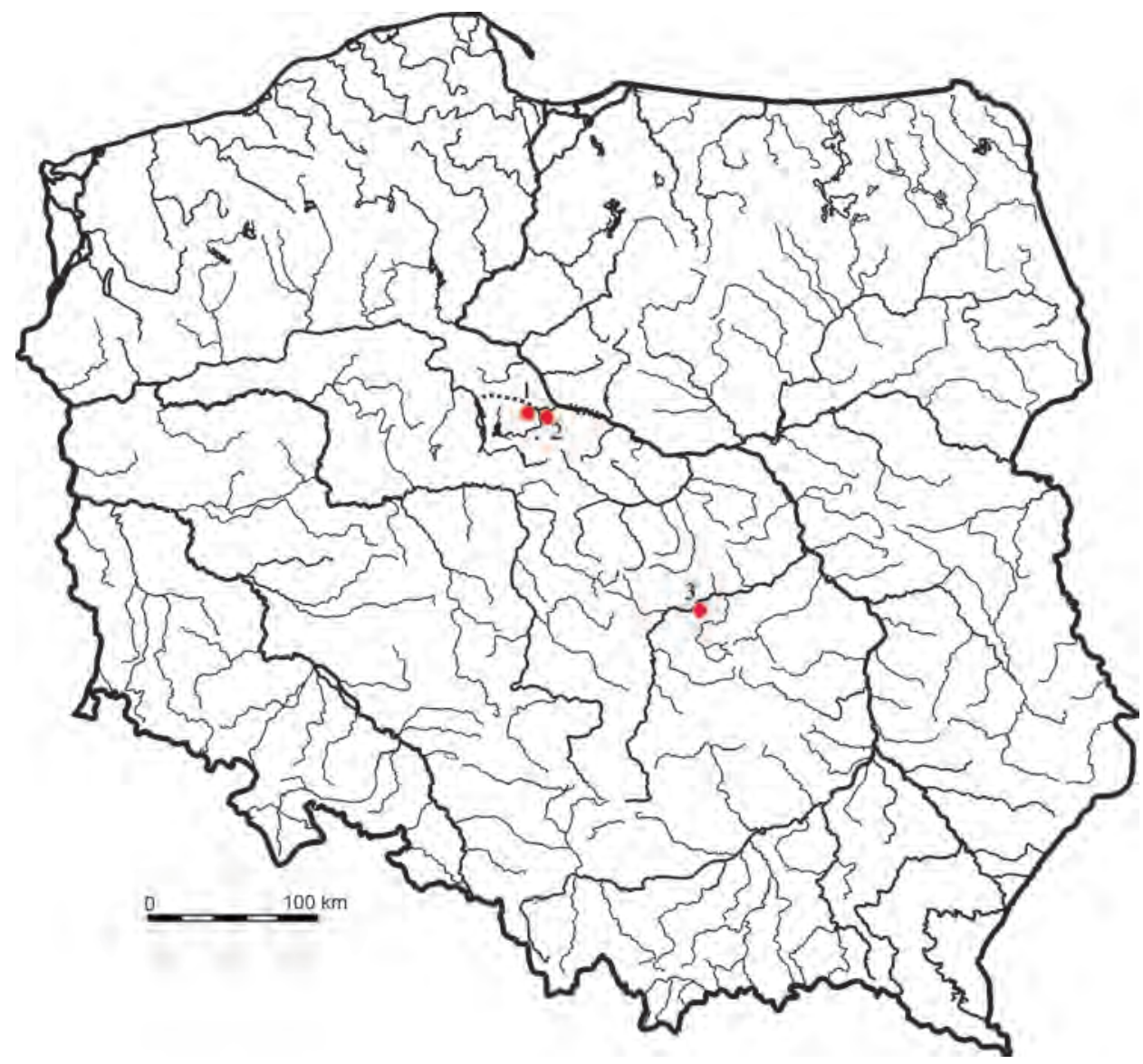

Fig. 1. Location of analysed sites. Red dots - location of mentioned sites: 1-Redecz Krukowy, Włocławek distr.; 2-Brześć Kujawski, Włocławek distr.; 3-Ponikła Fryszerka, Opoczno distr. Drawn: D. K. Płaza. 
Mesolithic Janislavice culture, early Neolithic Linear Band Pottery culture and middle Neolithic Funnel Beaker culture. In our opinion, these objects have clear features that could help with defining similarities or differences between those items and give suggestions about manner and goals of flint exploitation in the latter part of the Stone Age. We will discuss three 'chocolate' flint cores from three localities situated in central part of Poland - Ponikła Fryszerka, Opoczno district (Cyrek 1979), Brześć Kujawski (Grygiel 2004) and Redecz Krukowy, Włocławek district (Papiernik 20I2).

\section{EXPOSITION - THE SITES.}

The first, Mesolithic, core was discovered on the right bank of the valley of the Pilica River somewhere between the villages Ponikła and Fryszerka (Opoczno district), where a small stream, the Cetenka, joins the river. The site is situated on sandy plain and nowadays most of the terrain is covered by woods (Fig. 2). The single platform core

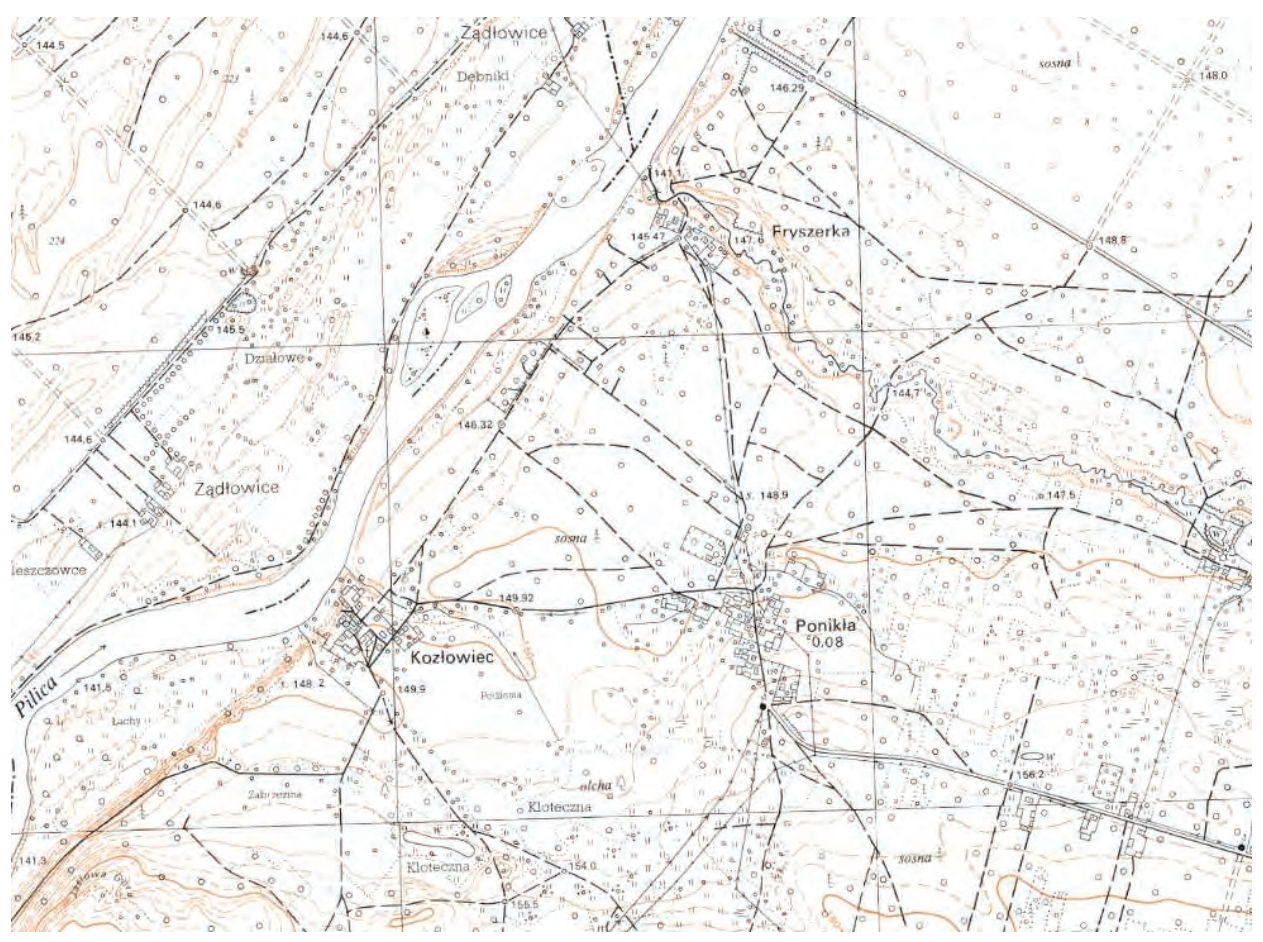

Fig. 2. Location of Ponikła and Fryszerka villages, Opoczno distr. Computer graphics: D. K. Płaza. 


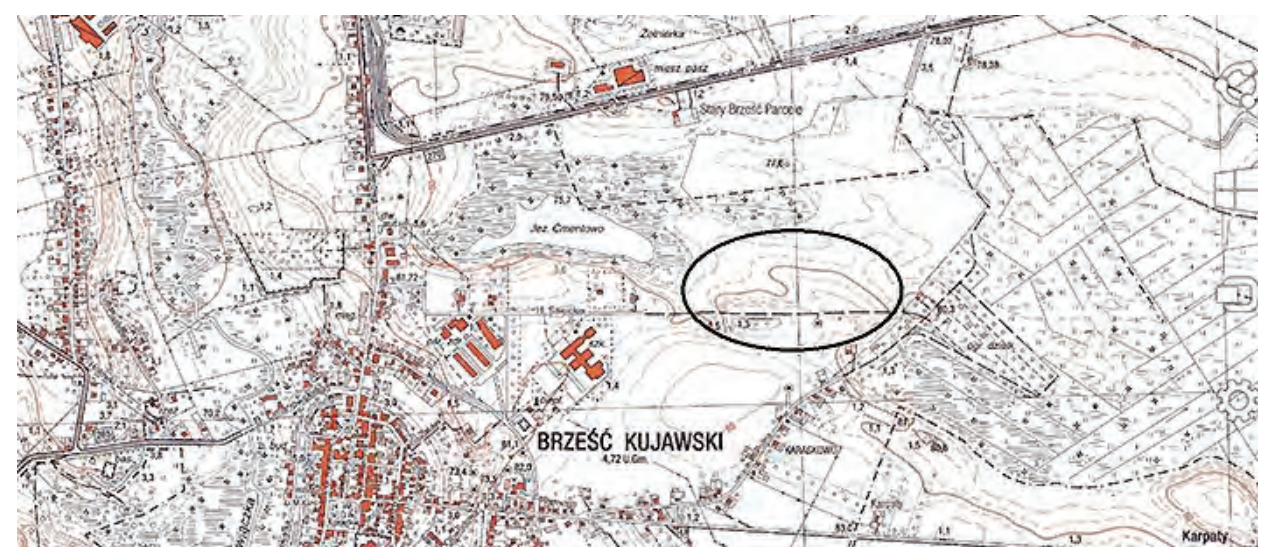

Fig. 3. Location of sites in Brześć Kujawski, Włocławek distr. Computer graphics: D. K. Płaza.

comes from field walking studies and it could be defined as an accidental find (Fig. 6). Due to characteristic features, there are no doubts that this core has late Mesolithic chronology (Cyrek 1979; Wąs 2005).

The second, early Neolithic, core was excavated from pit 592 on the Brześć Kujawski site 3, Włocławek district. This site is situated in middle part of Kuyavia and was discovered by Konrad Jażdżewski in 1933 and first explored by Stanisław Madajski in 1937. Subsequent excavations were carried out here forty years later, in 1977/1978 by Ryszard Grygiel together with Peter Bogucki (Grygiel 2004). Site 3 is a fragment of very famous large complex of early Neolithic settlement sites (number 3, 4 and 5) located in Brześć Kujawski on the southern bank of Smętowo Lake (Fig. 3). The site is situated on postglacial clay in which Neolithic farmers dug many pits where they finally threw garbage. A total area of 1975 square meters was excavated and, among the features discovered, I4 pits and 2 graves were linked with the Linear Band Pottery culture. One feature (pit 592), was a large clay pit with several niches that contained little amount of Early Neolithic materials including only six flint pieces but four of them were made from 'chocolate' flint. In one of the niches of this pit, a blade core in an advanced stage of exploitation with a single striking platform for striking blades and second platform used to produce flakes was discovered (Grygiel 2004: 170; Fig. 7).

The third, middle Neolithic, core come from most recent excavation which were conducted between 2006 and 2010 in Redecz Krukowy, Włocławek district (Papiernik 20I2; Fig. 4). Materials dated from the Mesolithic to modern time were discovered on this multicultural site. The site is situated on aeolian sand in which fossil soils were discovered. During five field seasons, together more than 13 months in the field, an area of 7487 square metres was excavated (Papiernik and Płaza 20I5). The site produced a huge amount of archaeological material, with more than $\mathrm{I} 4 \mathrm{O}, 000$ pottery fragments and around 25,000 flint pieces. Most of this material belonged to the earliest phase of the Funnel Beaker 


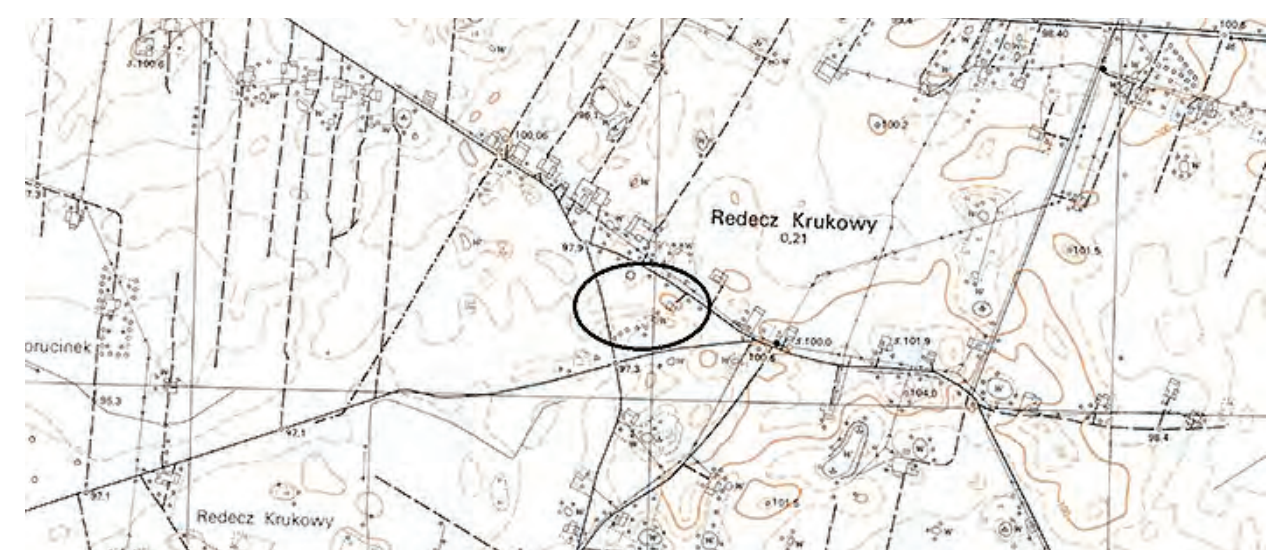

Fig. 4. Location of Redecz Krukowy site 20, Włocławek distr. Computer graphics: D. K. Płaza.

Culture (end of the V millennia and beginning of IV millennia BC). The assemblage of lithic raw materials is similar to other early Funnel Beaker culture sites (Niesiołowska 198I, 1986), with the domination of 'chocolate' flint. One of the most mysterious objects made from that material is a large single platform blade core in the early stages of blade exploitation (Fig. 8), which is one of the subjects of this article. It was discovered in the remains of the yard of one of the 'Sarnowo phase' house (Papiernik 20I2).

\section{RISING ACTION - THEORETICAL ASPECTS OF BLADE CORE ANALYSIS.}

Cores in general have a fundamental role in the chaine operatoire during lithic tool production. They come in a great variety of shapes, sizes and raw material and could be divided into formalized and informal cores (Andrefsky 2005). The formal core goes through a complicated process of preparation of angles, edges and surfaces. The informal type can be knapped without preparation in an opportunistic manner. From both cores is possible to obtain a good products, but the formalized core could give more easily be used to produce a series of similar, uniform pieces. A number of the side-products from core preparation also gave the chance for the production of other casual type of tools.

In the case of the three examples analysed here, they could all be classified as prepared, formal cores. They all exhibit visible traces of the stage of preparation, (shaping) which was followed by the striking of the opening blade and then serially produced blades.

Our idea is to analyse and compare the features on all three cores. For this reason we will divide the idealised single platform blade core (Fig. 5) into several sections that 


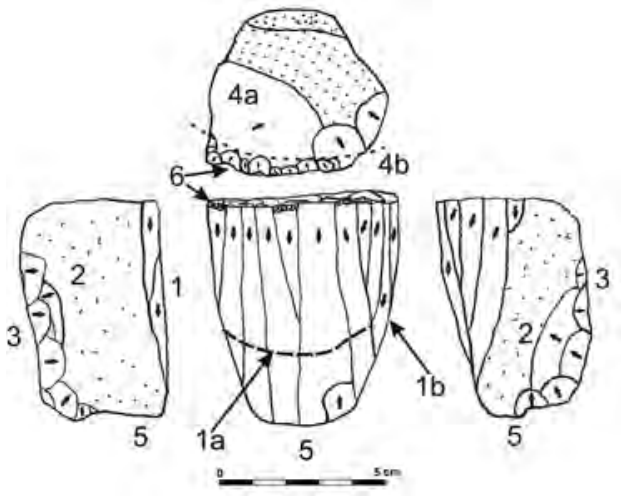

Fig. 5. Schematic core with described features and zones. Drawn: D. K. Płaza.

will be described and compared in the case of the actual archaeological artefacts. We will also analyse the dimensions and weight of all three pieces.

Each blade or flake core has to have clear features and zones like the flaking (debitage) surface with blade or flake negatives and ridges, a striking platform with traces of tablets or rejuvenation flake negatives, the sides sometimes with cortex, and the tip (Inizan et al., 1999).

In our ideal core (Fig. 5) we defined several zones:

- Frontal zone - flaking surface with active (Fig. 5:Ia) and passive part (Fig. 5:Ib),

- Two side zones (Fig. 5:2)

- Back zone (Fig. 5:3)

- Upper zone - striking platform (Fig. 5:4) with active (Fig. 5:I) and passive zone (Fig. 5:2; Wąs 2005)

- Lower zone - tip or prepared (Fig. 5:5).

In each active zone, there could be also observed micro-technological features like trimming, or abrasion (Fig. 5:6; Inizan et al., 1999). Another very interesting feature on the blade core is a horizontal curvature (Owen 1988; Wąs 20II: Fig. 2) which determines the width and depth of the active part of the flaking surface.

\section{CLIMAX - RESULTS OF ANALYSIS}

\section{First story - Core for microlithic arrowheads?}

The Mesolitihic core (Fig. 6) has a very regular - conical and symmetrical shape with the lower zone in the shape of a tip. It has a rectangular almost flat upper zone (striking platform) with just few irregularities on the edges, which are traces of the last blades that were struck from the core. Negatives of rejuvenation flakes cover almost $90 \%$ of that part. The active zone was less than I cm across and is located very close to the point of impact. On the frontal flaking surface and one side zone are visible 
\begin{tabular}{l|l} 
Three Stories About the Exploitation of 'Chocolate' Flint During the Stone Age in Central Poland & $7 \mathrm{I}$
\end{tabular}
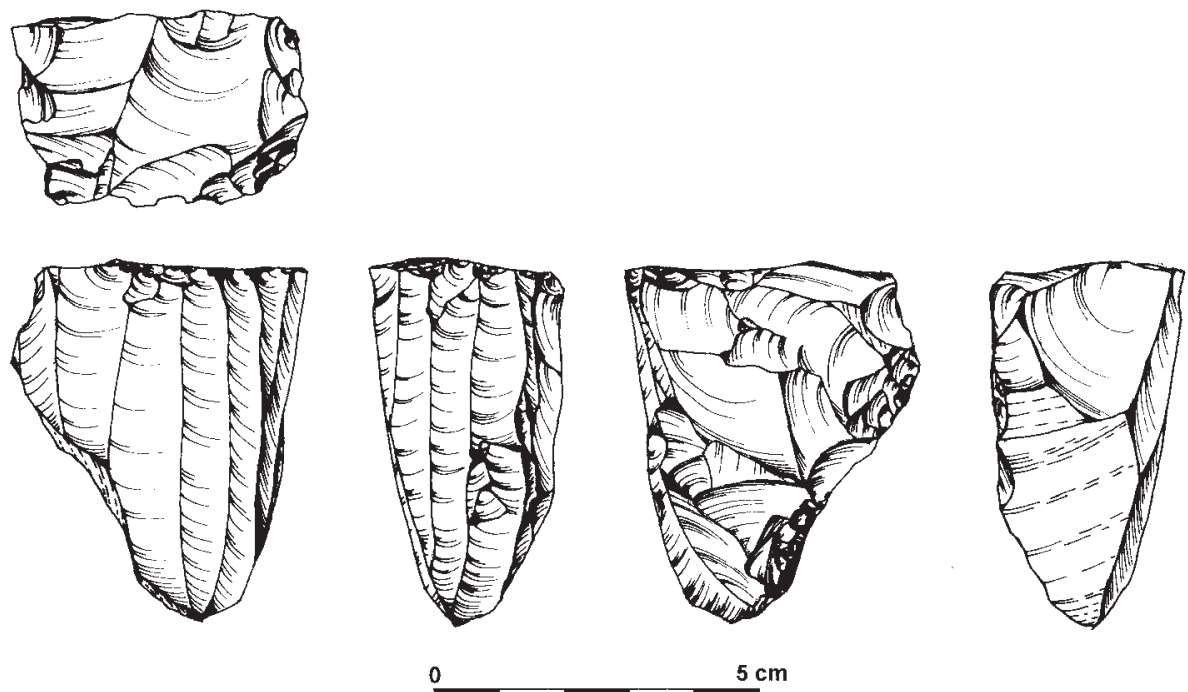

$5 \mathrm{~cm}$

Fig. 6. Ponikła Fryszerka, Opoczno distr., late Mesolithic core of Janislavice culture. Drawn: E. Górska.

regular parallel negatives left by the flaking of long and narrow blades. The broader frontal surface for extracting blades was used last and it could be named the active part. The narrower right side of the core should be considered the passive striking platform, which is confirmed by shortened negatives of blade from an earlier stage of blade production. At that stage, the longest blade was more than $5 \mathrm{~cm}$ long (Table I). Such a result indicates that it is not an exhausted core. There are II visible negatives of blades. The widths of the negatives after last blades are $0.8 \mathrm{I} \mathrm{cm}$ and $\mathrm{I} .2 \mathrm{I} \mathrm{cm}$. The ratio of the horizontal curvature of the core is 7.88 . The random indirect goal of the use of that core could be the creation of a bullet-shaped core but due to irregularity on the back zone and left side it was quite difficult to obtain that advanced shape of the core.

The direct goal of exploitation of that core was the production of long, regular and narrow blades which could be transformed into geometric microlithic arrow inserts, such as triangles or other type of Mesolithic Janislavice Culture points (Chmielewska 1954; Kozłowski 1989). Other parts of the core could give short flakes which could also be transformed into some ordinary tools.

Second story - Core for sickles?

The Early Neolithic core (Fig. 7) has quite a regular outline but less than the Mesolithic example. It has an irregular striking platform - the upper zone - with several medium and deep negatives after rejuvenation flake. An attempt was made to remove the irregularity on the top of the core by several flakes, but this was ineffective and resulted in several deep hinged flake negatives. The lack of success of this procedure 
Table. 1. Features of analysed cores.

\begin{tabular}{|c|c|c|c|c|}
\hline \multirow{3}{*}{ 象 } & Location & $\begin{array}{l}\text { Ponikła Fryszerka, } \\
\text { Opoczno district }\end{array}$ & \begin{tabular}{|l} 
Brześć Kujawski, \\
Włocłwek district
\end{tabular} & $\begin{array}{l}\text { Redecz Krukowy, } \\
\text { Włocławek district }\end{array}$ \\
\hline & Site number & & 3 & 20 \\
\hline & Chronology & Mesolithic & Early Neolithic & Middle Neolihic \\
\hline \multirow{4}{*}{ 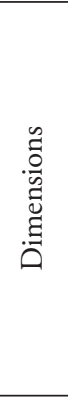 } & $\begin{array}{l}\text { Dimensions max lenght, } \\
\text { width, height. }\end{array}$ & $\begin{array}{l}\text { lenght }-5.49 \mathrm{~cm} \text {, } \\
\text { width }-2.88 \mathrm{~cm} \text {, } \\
\text { height }-4.23 \mathrm{~cm}\end{array}$ & $\begin{array}{l}\text { lenght }-7.05 \mathrm{~cm} \text {, } \\
\text { width }-5.41 \mathrm{~cm} \text {, } \\
\text { height }-5.42 \mathrm{~cm}\end{array}$ & $\begin{array}{l}\text { lenght }-10.35 \mathrm{~cm} \text {, } \\
\text { width }-6.61 \mathrm{~cm} \text {, } \\
\text { height }-9.73 \mathrm{~cm}\end{array}$ \\
\hline & $\begin{array}{l}\text { Ratio max lenght } \mathrm{x} \\
\text { weight - size value } \\
\text { (Andrefsky 2005) }\end{array}$ & $\begin{array}{l}5.49 \mathrm{~cm} \times 81 \mathrm{~g}= \\
444.69\end{array}$ & $\begin{array}{l}7.05 \mathrm{~cm} \times 174 \mathrm{~g}= \\
1226.1\end{array}$ & $\begin{array}{l}10.35 \mathrm{~cm} \mathrm{x} 867 \mathrm{~g}= \\
8973.45\end{array}$ \\
\hline & $\begin{array}{l}\text { Ratio max lenght : } \\
\text { weight - size value }\end{array}$ & $\begin{array}{l}5.49 \mathrm{~cm} \div 81 \mathrm{~g} \mathrm{x} \\
100=6.77\end{array}$ & $\begin{array}{l}7.05 \mathrm{~cm} \div 174 \mathrm{~g} \mathrm{x} \\
100=4.05\end{array}$ & $\begin{array}{l}10.35 \mathrm{~cm} \div 867 \mathrm{~g} \mathrm{x} \\
100=1.19\end{array}$ \\
\hline & $\begin{array}{l}\text { Ratio Horizontal curva- } \\
\text { ture (in } \mathrm{cm} \text { ) }\end{array}$ & $3.31 \div 0.42=7.88$ & $5.41 \div 1.98=2.73$ & $5.51 \div 2.82=1.95$ \\
\hline \multirow{4}{*}{ 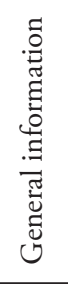 } & Shape from frontal zone & Conical & Squer & Rectangular \\
\hline & $\begin{array}{l}\text { Angle between front and } \\
\text { upper zone }\end{array}$ & $\begin{array}{l}\text { between } 80-90 \\
\text { degrees }\end{array}$ & around 80 degress & around 80 degress \\
\hline & Type of core & $\begin{array}{l}\text { Single platform } \\
\text { microblade core }\end{array}$ & $\begin{array}{l}\text { Single platform } \\
\text { blade core }\end{array}$ & $\begin{array}{l}\text { Single platform } \\
\text { blade core }\end{array}$ \\
\hline & $\begin{array}{l}\text { Number of flaking } \\
\text { surface }\end{array}$ & 1 - double sided & 2 & 1 \\
\hline \multirow{4}{*}{ 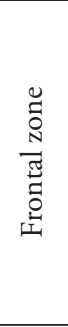 } & Technical features & $\begin{array}{l}\text { Partially abrasion } \\
\text { and facetted }\end{array}$ & Point abrasion & Point abrasion \\
\hline & System of negatives & Parallel & Parallel & Parallel \\
\hline & Longest blade & $5.49 \mathrm{~cm}$ & $4.61 \mathrm{~cm}$ & $8.45 \mathrm{~cm}$ \\
\hline & Regularity and riples & $\begin{array}{l}\text { Streight, very } \\
\text { regular. Ripples hard } \\
\text { to see. }\end{array}$ & $\begin{array}{l}\text { Streight, irregular in } \\
\text { middle and upper } \\
\text { section. Ripples } \\
\text { visible. }\end{array}$ & $\begin{array}{l}\text { Streight, very } \\
\text { regular. Ripples harc } \\
\text { to see. }\end{array}$ \\
\hline \multirow{3}{*}{ 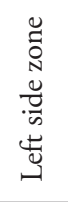 } & Negatives / cortex & $\begin{array}{l}\text { One flake and natu- } \\
\text { ral surface }\end{array}$ & Cortex & $\begin{array}{l}\text { Partial cortex and } \\
\text { flake negatives }\end{array}$ \\
\hline & Direction of negatives & \begin{tabular}{|l|}
$\begin{array}{l}\text { Parallel to other } \\
\text { parts of core }\end{array}$ \\
\end{tabular} & No negatives & Multidirectional \\
\hline & Shape & Conical & Trapezoid & Trapezoid \\
\hline \multirow{3}{*}{ 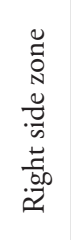 } & Negatives / cortex & Microblade negatives & $\begin{array}{l}\begin{array}{l}\text { Negatives of prepara- } \\
\text { tion flake }\end{array} \\
\end{array}$ & $\begin{array}{l}\text { Partial cortex, blade } \\
\text { and flake negatives }\end{array}$ \\
\hline & direction of negatives & $\begin{array}{l}\text { Oblique to other } \\
\text { parts of the core }\end{array}$ & Multidirectional & $\begin{array}{l}\text { Mostly parallel. One } \\
\text { flake from oposit } \\
\text { side }\end{array}$ \\
\hline & Shape & Conical & Trapezoid & Sub-conical \\
\hline
\end{tabular}


Three Stories About the Exploitation of 'Chocolate' Flint During the Stone Age in Central Poland

\begin{tabular}{|c|c|c|c|c|}
\hline \multirow{4}{*}{ 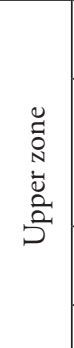 } & $\begin{array}{l}\text { Number of striking } \\
\text { platform }\end{array}$ & 1 & 2 & 1 \\
\hline & Technical features & $\begin{array}{l}\text { Passive zone with } \\
\text { large flake negatives, } \\
\text { active zone small } \\
\text { flake negatives }\end{array}$ & $\begin{array}{l}\text { Rejuvenation flake } \\
\text { negatives }\end{array}$ & $\begin{array}{l}\text { Active zone with } \\
\text { rejuvenation flake, } \\
\text { passive zone natural }\end{array}$ \\
\hline & System of negatives & Multidirectional & $\begin{array}{l}\text { Only frontal } \\
\text { direction }\end{array}$ & $\begin{array}{l}\text { Only frontal } \\
\text { direction }\end{array}$ \\
\hline & Shape & Rectangular & Oval & Oval \\
\hline \multirow{3}{*}{ 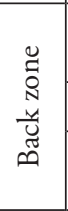 } & Negatives / cortex & $\begin{array}{l}\text { Negatives of prepara- } \\
\text { tion flake }\end{array}$ & Edge & $\begin{array}{l}\text { Partly natural and } \\
\text { edge }\end{array}$ \\
\hline & Direction of negatives & Multidirectional & Edge & One side - left \\
\hline & Shape & Triangle & Edge & $\begin{array}{l}\text { Flat - natural and } \\
\text { edge }\end{array}$ \\
\hline \multirow{2}{*}{ 峞 } & Direction of negatives & No & One side & Rohmboid \\
\hline & Shape & Tip & Trapezoid & Multidirection \\
\hline
\end{tabular}

could have been one of the reasons for discarding that core. On the flaking surface, in the frontal zone are visible several quite parallel but not very regular flake negatives left by the removal of varied blades, there are Io visible negatives. The widths of the flake negatives from the last blades are $0.97 \mathrm{~cm}$ and $1.77 \mathrm{~cm}$. The ratio of the horizontal curvature of the core is 2.72 . In this core only one flaking surface for blade production was used on the frontal side. It has semicircular convex shape. At that stage, the longest blade was less than $5 \mathrm{~cm}$ long (Table I). Such a result indicates that it should be considered to be an exhausted core. The left zone is fully covered in cortex and the right zone has visible negatives of preparation flaking. The back zone is formed as an edge. One of the most important points was the narrow flat basal part - the lower zone that determined the form of the produced blades. This zone was shaped with two large flakes made at quite an early stage of exploitation.

The blades were not so long, quite broad and had a rectangular end. That kind of blade was the direct goal of production. Such a blade was most important in the further transformation into tools like truncation or endscrapers rather than those used, among others, to produce sickle inserts in the Linear Band Pottery culture (Siciński et al., 20I6).

\section{Third story - Core for a long knife?}

The Middle Neolithic core (Fig. 8) has very regular form even that it was discarded in quite an early stage of exploitation. Its striking platform has a regular shape and is flat, the upper zone has io medium and small, rather flat negatives after rejuvenation flake ]which create the short active part of that zone. Most of the upper zone is natural and could be classified as a passive part. There are parallel and regular negatives from the 

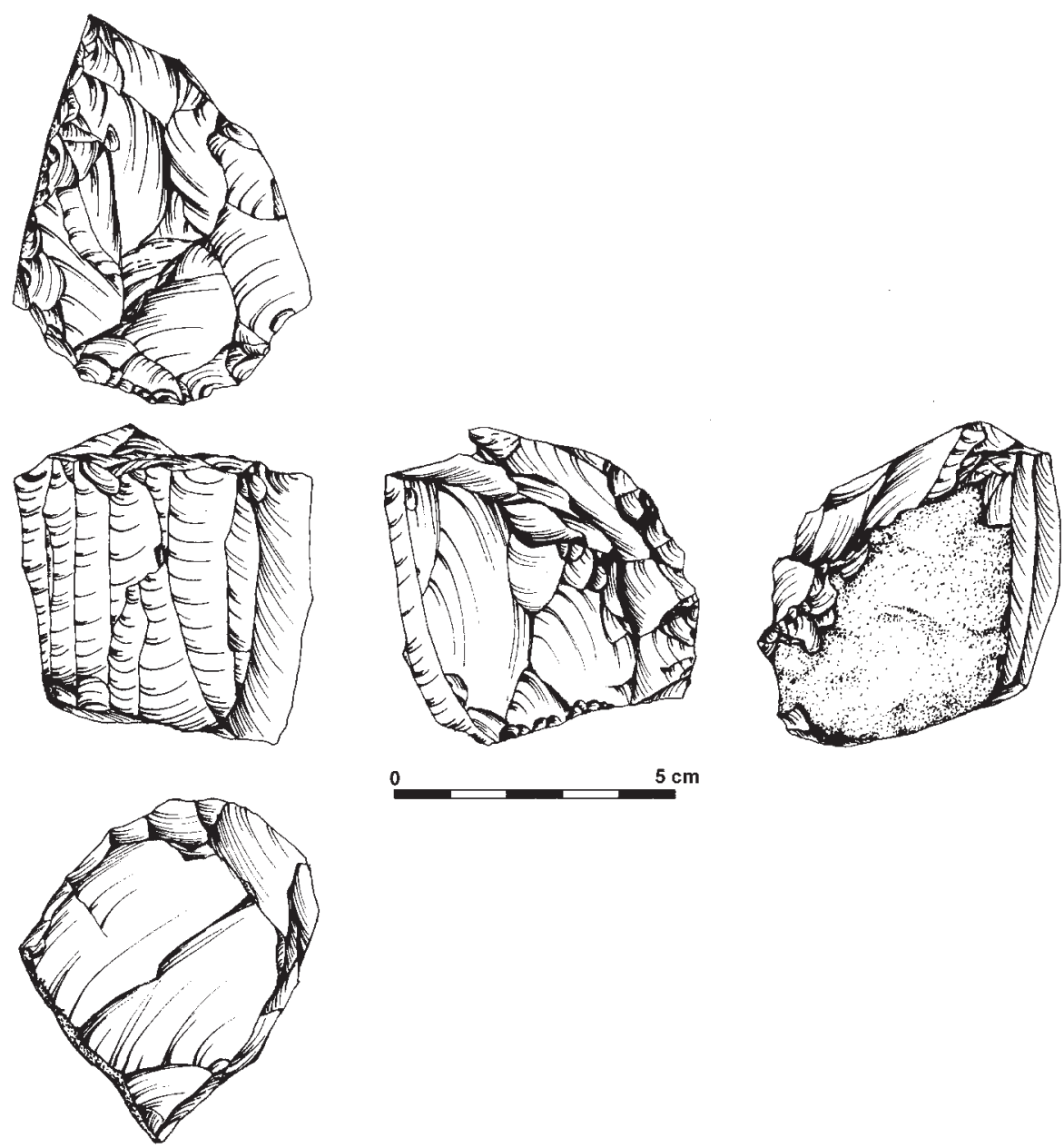

Fig. 7. Brześć Kujawski, Włocławek distr., early Neolithic core of Linear Band Pottery culture.

Drawn: E. Górska.

production of long blades visible on the flaking surface - the frontal zone. There are 8 visible negatives of blades in this part. The width of the last blades negatives are $\mathrm{I} .6 \mathrm{I} \mathrm{cm}$ and $1.93 \mathrm{~cm}$. On that core, only one rather narrow flaking surface for blade production was used on the frontal zone. The ratio of the horizontal curvature of the core is I.95. After reduction of bottom zone, it has a rectangular semi-oval shape. At that stage, the longest blade was more than $8 \mathrm{~cm}$ long (Table I). That observation indicates that this core was discarded at the early stage of blade production. Both left and right zone are similar with preserved traces of the preparation stage when cortical flakes were produced. 


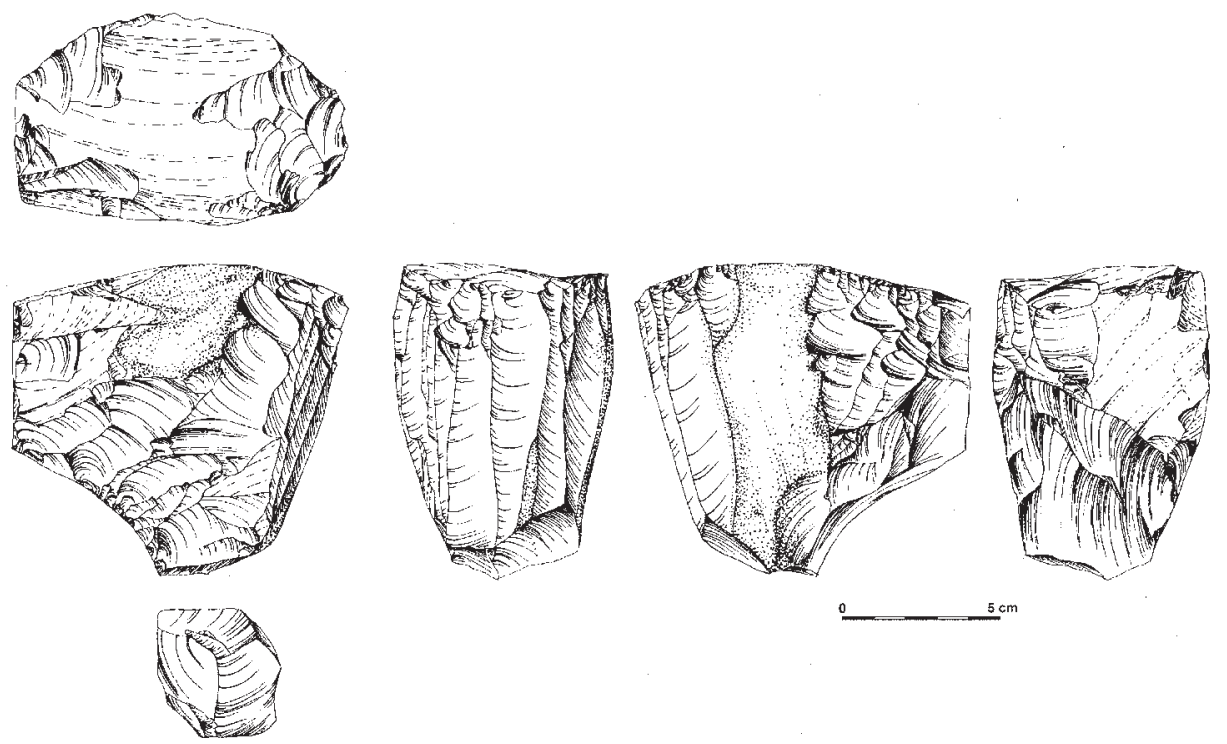

Fig. 8. Redecz Krukowy, Włocławek distr., middle Neolithic core of Funnel Beaker Culture.

Drawn: E. Górska.

It is important to note that among several thousand flakes from this site, there was not a single one that could be refitted to this core (Papiernik and Płaza 20I5). This could indicate that the core underwent the preparation procedure in a different place from the site in Redecz Krukowy. The back zone was formed as an edge with a small part left in natural surface condition. In that case, another important point was the prepared basal part - the lower zone that determined the shape of the produced blades. It was shaped by at least three flakes.

Due to the broad lower zone, blades were long enough and not plunging (Inizan et al., 1999: Fig. 149-150). Producing that kind of straight, regular blade was the main and only goal in the use of this core. Blades of that type were useful for transformation into tools like the knives, endscrapers or sickle inserts used in Funnel Beaker culture. The most important fact is that, in our opinion, the core discussed here, and most of the blades at Redecz Krukowy had been made in another place, maybe near the outcrops of 'chocolate' flint.

\section{FALLING ACTIONS - SIMILARITIES AND DIFFERENCES}

In general overview, the three cores are very similar, but precise study points to clear and significant differences between them in almost all the defined zones. The analysed 
76 Ptaza and Papiernik

pieces are all single platform blade cores with traces of impact on the striking platform (zone I; Fig. 4:I). The first important difference is located in that zone. On the Mesolithic core, soft and delicate traces of trimming together with short flake negatives from corerejuvenation flakes are seen in the active zone. Earlier large preparation flaking created the passive zone of the striking platform. On the Early Neolithic core, there are traces of extremely strong, multidirectional impacts. It is difficult to separate an active and passive zone of the striking platform in the case of this core. The core of the Funnel Beaker culture however has a clear division between the active and passive sections with quite a similar ratio of horizontal curvature to early Neolithic core from Brzesc Kujawski. The flaking surface on the Funnel Beaker culture core are rather similar to early Neolithic core without division into passive and active zones in that part. On blades from such a core, the ridges should have parallel negatives. In contrast, the Mesolithic core has that zone - flaking surface separated into two sides that define an active and passive section. When the passive zone would be transformed into an active one, the negatives on the first blade would be diagonal, with some elements of the older active part preserved. Also the blade negatives left by the last blades of the earlier part are more regular and narrow, which reflect production of blades further used as arrow or harpoon inserts.

The back of the Mesolithic example looks like a flat prepared surface, triangular in shape. Both the Early Neolithic and Middle Neolithic ones have backs formed as an edge.

The lower part in both Neolithic cores looks similar and is formed as a rather flat surface with several flakes and that of the Mesolithic core has a conical shape, so the lower part is formed as a tip. The use of micro-technological features like trimming, or abrasion is also significant. It was most important on the Mesolithic core, but both Neolithic examples have less clear traces of that procedure.

\section{EPILOGUE - CONCLUDING REMARKS}

The above comments about blade cores show the complications of the story of the use of cores in the latter part of the Stone Age in the Polish lowlands. The three cores have many common features and some very important differences. One clear difference which has not been mentioned before are the overall dimensions which differentiate all three examples (Fig. 9; Table I).

One of the reasons that induced us to undertake this work was the necessity to present the features of the Funnel Beaker culture blade core from Redecz Krukowy. Our inspiration was a paper of $201 \mathrm{I}$ of Marcin Wąs, and the information supplied here can be treated as a supplement to his work. He considered flint materials connected with two cultural units, the Janislavice Culture and Linear Band Pottery culture, and concluded that those societies had two different conceptions of blade production. This statement was supported by the clearly different strategy of half-raw material 

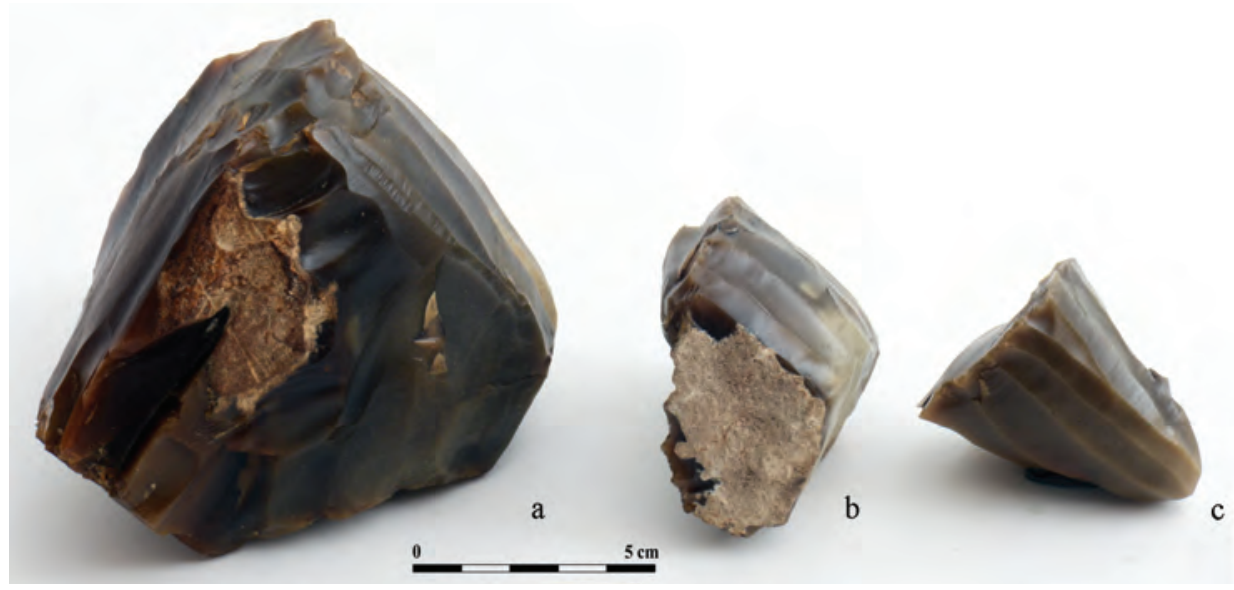

Fig. 9. Photo of the analysed cores: a - Redecz Krukowy, Włocławek distr.; b - Brześć Kujawski, Włocławek distr.; c - Ponikła Fryszerka, Opoczno distr. Photo: W. Pohorecki.

use, and use of blades and tools. Our studies of the blade core from Redecz Krukowy supplement our knowledge about the use of 'chocolate' flint during the Stone Age and shows another strategy and behaviour connected with flint processing and the use of tools. In our opinion, the core has more features in common with the 'Danube culture flintknapping strategy' than with the 'Mesolithic flintknapping strategy'.

The main question about the Redecz Krukowy 'chocolate' flint materials is whether the Funnel Beaker culture farmers could process that kind of flint for blades by themselves in the Polish lowlands. We hope that the answer will come in monographic presentation of the site soon.

\section{REFERENCES}

Andrefsky, W. Jr. 1998. Lithics: Macroscopic Approaches to Analysis. Cambridge, Cambridge Manuals in Archaeology.

Budziszewski, J. 2008. Stan badań nad występowaniem i pradziejową eksploatacją krzemieni czekoladowych. In W. Borkowski, J. Libera, B. Sałacińska and S. Sałaciński (eds), Krzemień czekoladowy w pradziejach. Materiaty z konferencji w Orońsku, o8-10.10.2003, 33-I06. Warszawa-Lublin, Studia nad Gospodarką surowcami krzemiennymi w pradziejach 7.

Cyrek, M. 1979. Schyłkowo paleolityczne i mezolityczne materiały krzemienne z badań powierzchniowych nad Pilica. Prace i Materiaty Muzeum Archeologicznego i Etnograficznego w Eodzi, Seria archeologiczna 26: 5-40.

Freytag, G. 1900. Freytag's Technique of the Drama, An Exposition of Dramatic Composition and Art by Dr. Gustav Freytag: An Authorized Translation From the Sixth German Edition by Elias J. MacEwan, M.A. (3rded.). Chicago, Scott, Foresman and Company. 
Grygiel, R. 2004. Neolit i początki epoki brązu w rejonie Brześcia Kujawskiego i Ostonek. Volume I: Wczesny neolit. Kultura ceramiki wstegowej rytej. Łódź.

Inizan, M.-L., Reduron-Ballinger M., Roche H. and Tixier, J. 1999. Technology and Terminology of Knapped Stone. Nanterre, C.R.E.P.

Kozłowski, S.K. 1989. Mesolithic in Poland. Warszawa.

Niesiołowska, E. 198I. Niektóre problemy związane z materiałami krzemiennymi kultury pucharów lejkowatych z fazy AB, pochodzącymi z grobowca 8 w Sarnowie, woj. włocławskim. In T. Wiślański (ed.), Kultura pucharów lejkowatych w Polsce (studia i materiaty), 37-57. Poznań.

Niesiołowska, E. 1986. Materiały krzemienne z grobowca 9 w Sarnowie, województwo włocławskie, na the fazy sarnowskiej KPL. Prace i Materiaty Muzeum Archeologicznego i Etnograficznego w Eodzi. Seria Archeologiczna 33, 23-48.

Owen, L. 1988. Blade and Microblade Technology. Selected Assemblages from the North American Arctic and the Upper Paleolithic of Southwest Germany. Oxford, British Archaeological Reports, International Series 44I.

Papiernik, P. 2012 (20IO-20I2). Sprawozdanie z badań wykopaliskowych na stanowisku 20 w Redczu Krukowym, pow. włocławski, woj. kujawsko-pomorskie. Prace i Materiaty Muzeum Archeologicznego i Etnograficznego w Łodzi. Seria Archeologiczna 45: 195-238.

Papiernik, P. and Płaza D.K. 20I5. Zagospodarowanie przestrzeni w środkowej i młodszej epoce kamienia na stanowisku Redecz Krukowy 20, gm. Brześć Kujawski, woj. kujawsko-pomorskie, w świetle metody składanek. Acta Universitatis Nicolai Copernici Archeologia 34: 217-236

Schild, R., Królik, H. and Marczak, M. 1985. Kopalnia krzemienia czekoladowego w Tomaszowie. Wrocław-Warszawa-Kraków-Gdańsk.

Siciński, W., Płaza, D.K. and Papiernik, P. 2016. Ratownicze badania archeologiczne na stanowisku Io w Kruszynie, pow. wtoctawek, woj. kujawsko-pomorskie (trasa autostrady A-I). Łódź.

Wąs, M. 2005. Technologia krzemieniarstwa kultury janisławickiej. Monografie Instytutu Archeologii Uniwersytetu Łódzkiego, Vol. III. Łódź.

Wąs, M. 20II. „Janisławickie” i „wstęgowe” koncepcje rdzeniowania wiórowego. Próba konfrontacji technologicznej. Folia Archaeologica 28: 5-23. 